\title{
Žáci se smějí učitelům: podoby a funkce školního humoru zaměřeného na učitele
}

\author{
Klára Šed’ová \\ Masarykova univerzita, Filozofická fakulta, Ústav pedagogických věd
}

Redakci zasláno 14. 12. 2011 / Do tisku přijato 14. 3. 2012

\begin{abstract}
Abstrakt: Článek je věnován otázce žákovského humoru zaměřeného na učitele v prostředídruhého stupně základní školy a je založen na analýze písemných vyprávění žáků. Získaná data jsou kategorizována podle různých situačních modů, v nichž se učitel jako objekt humoru ocitá - modus nezáměrné komiky, modus žákovské léčky a modus učitelského vtipu. Analýza ukazuje řadu funkcí školního humoru, především co se týče přijatelného vyjádření hostilních pocitů žáků i učitelů.
\end{abstract}

Klíčová slova: učitel, žáci, škola, humor, funkce humoru

\section{1 Úvodem}

Cílem tohoto textu je prozkoumat podoby a funkce humoru ve školním prostředí. Protože jde o poměrně široké zadání, zúžíme jej pouze na ty situace, které se odehrávají v interakci mezi učitelem a žáky a v nichž je zdrojem humoru či komiky učitel. Znamená to, že budeme zkoumat incidenty, kdy se žáci smějí učitelům, at' už se tito stávají objektem humoru dobrovolně, či nedobrovolně. Svá tvrzení ohledně povahy tohoto druhu školního humoru založíme na analýze žákovských textů popisujících humorný zážitek ze školního prostředí.

\section{Co je humor}

Podle Bariauda (1989) je humor specifický typ zážitku vyvěrající z percepce či evokace směšné či zábavné události. Termín humor lze vztáhnout jak ke vnímání (humorná reakce), tak k vytváření (humorná akce) něčeho směšného. Podstatou humoru je, jak se shodují autoři napříč různými disciplínami, určitá inkongruita, tedy simultánní výskyt elementů, které jsou vzájemně nekompatibilní nebo je jejich spojení nějak překvapivé či šokující. Pokud např́iklad učitel zaspí a přijde pozdě na vyučování, vnímáme to jako humorné, protože se to neslučuje s jeho rolí strážce školních pravidel. 
Pro produkci i percepci humoru je dále podstatný hravý rámec (Bariaud, 1989, s. 18), to znamená, že musí být vyslán signál, že to, co se ř́ká, není myšleno vážně. Wolfensteinová (1978, s. 196) uvádí, že dospělí lidé operují ve dvou různých diskurzech - seriózním a humorném. Co je vhodné a žádoucí $\mathrm{v}$ jednom diskurzu je naopak nepřijatelné v tom druhém. Zatímco dospělí bez potíží reagují na signály svých komunikačních partnerů a přecházejí z jednoho diskurzu do druhého, pro děti takovéto rozlišování samozřejmé není a musí se mu postupně učit. Z existence hravého rámce vyplývá důležitá vlastnost humoru, kterou je ambivalence. Humor nám umožňuje říci určitou věc a přitom ji zároveň popř́ít (jde o vtip, není to míněno vážně). Jak uvádí Mulkay (1988, s. 213-223), humor bývá užíván v situacích, kdy vážné sdělení přináší potenciální riziko konfrontace či zahanbení. Žertovná poloha umožňuje sdělit informaci a přitom nezávazně testovat reakci př́ijemce.

Humor může nabývat velmi různých forem. Martin (2007, s. 11) rozlišuje tři základní: může jít o vtipy, tedy předem připravené humorné promluvy anekdotického charakteru, o spontánní konverzační humor, tedy žerty předem neplánované, avšak záměrně vytvářené v průběhu sociální interakce a konečně o náhodný nezáměrný humor, tedy o různá přeřeknutí, chybné úkony či nehody, které jsou vnímány jako humorné.

Humor má svou stránku kognitivní i emocionální. Co se týče kognitivních procesů, je třeba, aby si jednotlivec povšiml inkongruentních elementů, rozpoznal hravý rámec zprávy a dokázal zprávu smysluplně interpretovat. Wanzerová et al. (2010, s. 7) uvádějí, že tvorba a percepce humoru sleduje následující algoritmus: nejprve je vyslána humorná zpráva, př́ijemce bud' rozpozná, nebo nerozpozná inkongruitu ve zprávě obsaženou. Pokud ji rozpozná, musí jí vzápětí přiřknout určitý nový význam, jinak je zpráva vnímána jako nesmyslná či bizarní.

Emoce jsou při tvorbě a percepci humoru rovněž přítomné. Typicky se uvádí, že humor vyvolává pozitivní emoce, které bývají manifestovány úsměvem či smíchem. To však nemusí platit vždy. Podle Wanzerové et al. (2010) po kognitivním přečtení humorné zprávy (viz výše) následuje její emocionální vyhodnocení. Existuje tzv. nevhodný humor, ${ }^{1}$ který u př́ijemce vyvolává naopak emoce negativní.

1 Jedná se např́́klad o stereotypizované vtipy týkající se genderu, národnosti či etnicity. Tyto vtipy jsou př́ijemcem vnímány negativně především tehdy, je-li sám členem skupiny, jíž se vtip týká, nebo s touto skupinou sympatizuje (srov. La Fave, 1972). 
Posledním důležitým aspektem humoru, který je na tomto místě třeba zmínit, je jeho sociální kontext. Jak uvádí Martin (2007, s. 5), humor obvykle předpokládá př́tomnost alespoň dvou osob. Obvykle se někomu smějeme nebo pro někoho vyprávíme vtipy. I když zažíváme něco směšného o samotě, mívá tato událost pseudosociální ráz - smějeme se např́íklad při vzpomínce na jinou osobu, při čtení zábavného textu, který napsala jiná osoba, apod. V jakékoli humorné situaci lze obvykle rozlišit tvůrce humoru - např. toho, kdo vypráví vtip, př́ijemce humoru - toho, kdo se vtipu směje, a objekt humoru - toho, o kom vtip pojednává (Ziv, 2010).

\section{Funkce humoru}

Schopnost humoru vyvolat pocity radosti a zvýšené energie a naopak působit proti skleslosti, úzkosti a napětí byla potvrzena řadou psychologických experimentů (viz např. Martin, 2007). Vedle toho bývá humoru přičítána řada dalších funkcí. $\mathrm{Na}$ individuální úrovni je humor chápán především jako mechanismus zvládání nepř́ijemné reality, jako způsob, jak se od ní odpoutat. Podle Freuda (česky 1995) bývají latentním obsahem humoru a vtipu především sexuální a agresivní motivy, jejichž seriózní vyjádření je společensky nepřijatelné. Prostřednictvím humoru vlastně můžeme říci něco zakázaného a užít si to bez pocitu viny. Wolfensteinová (1978, s. 25) uvádí, že podstatou humoru je transformace bolestivého do zábavného. Děti používají humor v situacích, které vzbuzují úzkost, vinu, nebo zklamání, aby transformovaly nepř́ijemné emoce na př́ijemné.

Vzhledem $\mathrm{k}$ tomu, že se humor odehrává obvykle $\mathrm{v}$ sociálním kontextu, nepřekvapí, že jsou mu přičítány četné sociální funkce. Za klasické je považováno tvrzení H. Bergsona (česky 1994), že smích a komično jsou obrannou reakcí společnosti na jevy a chování, které jsou antisociální povahy. Smích je v Bergsonově pojetí především výsměchem, v osobě, která je předmětem humoru má vzbudit trapný pocit a podnítit ji ke korekci vlastního jednání. S tezí, že humor přispívá k obraně skupinových norem, souhlasí řada dalších autorů (např. Woods, 1983; Ziv, 2010), vedle toho se jako klíčová sociální funkce humoru uvádí upevňování pout ve skupině prostřednictvím sdílených vtipů a žertů a snižování tenze a napětí (např. Martineau, 1972; Koller, 1988; Ziv, 2010).

Jiných významů nabývá humor ve vztahu ke členům cizí skupiny - vymezuje hranice vlastní skupiny a brání ji před průnikem outsiderů, kteří nerozumí 
sdíleným vtipům (Ziv, 2010). Jak uvádí Martineau (1972), humor zaměřený na cizí skupinu je často hostilní a výsměšný, což plní výše uvedenou funkci, pokud však obsahuje pozitivní evaluační aspekt, může naopak podporovat sbližování různých skupin (například učitelů a žáků).

\section{Zkoumání humoru ve školním prostředí}

Ačkoli nejde o prominentní téma pedagogického výzkumu, zkoumání humoru ve školním prostředí má svoji tradici. V českém kontextu lze zmínit, že je téma humoru poměrně extenzivně obsaženo v klasické monografii a komunikaci ve škole Mareše a Křivohlavého (1995), původní empirické výzkumy však u nás téměř absentují.

V zahraničí je nejčastějším předmětem akademického zájmu otázka, zda má použití humoru nějaký pozitivní dopad na žákovské učení. Realizované výzkumy (byt' s poněkud kolísavými výsledky) svědčí o tom, že použití humoru vede k lepšímu zapamatování vyučovaných obsahů (Garner, 2006; Carlson, 2011), zvyšuje zájem a motivaci k učení (Matrazzo et al., 2010), vede k lepšímu pochopení konceptů a idejí (Garner, 2006; Bingham \& Hernandez, 2009), posiluje žákovskou kreativitu (Ziv, 1976).

Vedle zkoumání pedagogické efektivity jsou dostupné výzkumy zaměřující se na to, jak humor intervenuje do interpersonálních vztahů, at' už mezi učitelem a žáky, nebo $\mathrm{v}$ rámci žákovské skupiny. $\mathrm{V}$ této skupině dominují studie sledující vliv humoru na blízkost mezi učitelem a žáky (Gorham \& Christophel, 1990; Dunleavy, 2006; Wanzer et al., 2010), které ověřují předpoklad, že užití humoru učitelem přispívá $\mathrm{k}$ vytvoření pozitivního afektivního klimatu ve třídě.

Centrem pozornosti je $\mathrm{v}$ takto designovaných výzkumech učitel, který je tvůrcem humoru, vede žáky k lepšímu učení nebo si s nimi vytváří blízký vztah. Studie, které by vycházely primárně z perspektivy žáků, jsou mnohem méně početné. Za klasické lze považovat práce Woodse $(1979,1983)$, který chápe humor především jako copingovou strategii a ukazuje, jak užití humoru pomáhá žákům i učitelům vyrovnávat se s požadavky školní instituce a zvládat je. Podle Woodse $(1983$, s. 112) lze humor ve třídě použít dvěma různými způsoby. Prvním způsobem je facilitace, to znamená zlepšení vztahů mezi žáky a učitelem, nastolení harmonie, vytvoření či posílení sdílené definice situace. Druhým způsobem je rezistence, to znamená vyjádření a posílení opačného stanoviska či přímo odporu. 
Novější výzkumy žákovského humoru se orientují především na roli humoru při utváření vztahů uvnitř žákovské skupiny (viz např. Lahelma, 2002; Klein \& Kuiper, 2006; Huuki et al., 2010). Tyto studie konstatují, že humor je jedním ze zdrojů, jichž žáci využívají k dosažení sociálního statusu v dětské skupině. Žáci hodnocení jako vtipní či zábavní na jedné straně vykazují vysokou popularitu mezi spolužáky, na druhé straně vykazují vyšší míru agresivity než ostatní. Tyto studie často poukazují na relativně tenkou hranici mezi legrací a šikanou.

Žákovský humor zaměřený na učitele zůstává ovšem jen málo zmapovaným tématem. Výjimku představuje práce Meeuse a Mahieu (2009) kteří, podobně jako je tomu v tomto textu, analyzovali písemná vyprávění týkající se humorných zážitků $s$ učiteli. Respondenty v jejich výzkumu (na rozdíl od této studie) byli vysokoškolští studenti, kteří vzpomínali na dobu své povinné školní docházky. Meeus a Mahieu (2009) identifikovali několik klíčových motivů žákovského humoru: (1) oslava - humorná příhoda, která se odehrála během nějak mimořádného školního dne; (2) testování učitelů pomocí škádlení a legrácek; (3) „náprava“ učitele, který má nějaké nepř́ijemné charakteristiky; (4) rebelování vůči př́isným učitelům; (5) nekázeň v hodinách nedostatečně autoritativních učitelů; (6) vytváření př́ijemné atmosféry - radostné formy humoru, které nejsou zaměřeny proti učitelům. Jde o typologii, která by byla aplikovatelná i na naše data (ačkoli $\mathrm{v}$ tomto textu používáme jinou kategorizaci). Za povšimnutí stojí skutečnost, že čtyři ze šesti kategorií - testování, náprava, rebelování a nekázeň - v sobě zahrnují nějakou formu konfliktu mezi žáky a učiteli. Výzkum Meeuse a Mahieu (2009) tedy naznačuje, že žáci užívají humor spíše jako nástroj rezistence, než facilitace (srov. Woods, 1983).

\section{Metodologie realizovaného empirického šetření}

V další části tohoto textu předložíme výsledky vlastního empirického šetření, které je založeno na analýze žákovských textů popisujících humorný zážitek v prostředí školy. Autory těchto textů jsou žáci druhého stupně základní školy, kteři dostali zadání zpracovat písemné vyprávění na téma „humorná příhoda ze školy“. Data byla sbírána v březnu a dubnu 2011 ve spolupráci se studenty Ústavu pedagogických věd Filozofické fakulty Masarykovy univerzity. ${ }^{2}$ Celý vzorek tvoři 137 nasbíraných textů doplněných o identifikační formuláře

2 Šlo o frekventanty kurzu Sociologie výchovy, kteří byli instruováni, jakým způsobem data sbírat. 
s vybranými údaji o autorech textů (pohlaví, věk, prospěch atd.). Žáci psali svá vyprávění rukou, následně byla tato vyprávění přesně (tedy i s gramatickými chybami či použitými vulgarismy) přepsána do elektronické verze.

Z pořízeného vzorku byly pro účely tohoto článku vybrány pouze ty texty, kde je objektem humoru učitel. Přitom jsme vyjmuli ty texty, které by sice splňovaly toto kritérium, ale které se vázaly $\mathrm{k}$ nějaké mimořádné události školního života, jako je např́iklad apríl nebo výjezd na lyžařský kurz, a které obsahovaly celý řetězec humorných událostí se strrídajícími se objekty humoru (žáci i učitelé). Výsledný vzorek je tvořen 52 žákovskými pracemi. $\mathrm{V}$ tomto vzorku jsou výrazně nadreprezentovány dívky, které napsaly 38 textů oproti 13 textům chlapeckým. ${ }^{3}$ Co se týče rozložení po jednotlivých ročnících druhého stupně, 9 textů napsali žáci 6. ročníku, 15 textů žáci 7. ročníku, 10 textů žáci 8. ročníku a 17 textů pochází z pera žáků 9. ročníku. Z hlediska velikosti sídla školy jsou nejvíce zastoupeni respondenti z velkých (krajských) měst, jichž je ve vzorku 21. Malé město a vesnice (obec s jednou školou) jsou zastoupeny shodně 15 texty.

Písemná vyprávění žáků, jak uvádí Woods (1986), mohou být vynikajícím zdrojem empirických dat. Žáci sami vytvářejí popis situace, která ve škole nastala, a tím pádem vlastně „zastupují“ výzkumníka, který by za jiných okolností tyto situace sám sledoval a pořizoval si o nich poznámky (Woods, 1986, s. 98). Hlavní výhodou této metody je dosažení vnitřní perspektivy aktérů, jež je považováno za jeden $\mathrm{z}$ definičních znaků kvalitativního výzkumu. Pokud bychom sledovali projevy humoru kupříkladu přímým pozorováním komunikace ve vyučovací hodině, museli bychom se vždy řídit zprostředkovanými indikátory, jako jsou úsměvy či smích žáků, abychom si mohli být jisti, že je určitá situace vnímána jako humorná. Tato komplikace při studiu žákovských textů na zadané téma odpadá, nebot’ si můžeme být jisti, že to, co žáci popisují, považují za humorné, vtipné či legrační.

Na druhou stranu je třeba mít na zřeteli, že žákovská vyprávění nelze brát jako přesnou rekonstrukci události, kterou popisují. Jednak je zaznamenaný incident vždy líčen ze subjektivní pozice autora textu (často s evidentním

\footnotetext{
Převaha dívek je dána jejich vyšší ochotou zapojit se do výzkumu, jehož předpokladem je sepsání souvislého písemného vyprávění. Tato převaha se týká i celého vzorku 137 žákovských textů, ale není tak výrazná jako v tomto dílčím vzorku (92 dívčích ku 45 chlapeckým textům). Můžeme to interpretovat tak, že pokud dívky líčí humornou příhodu z prostředí školy, koncentrují se především na humor, jehož zdrojem jsou učitelé (nikoli například na humor uvnitř žákovské skupiny).
} 
emocionálním zabarvením), jednak jde o popis události, která se odehrála v různě vzdálené minulosti, a vzpomínky tudíž mohou být dílčí, selektivní a fragmentární. Nemůžeme si být jisti, že se popisované události odehrály přesně tak, jak žáci popisují. Co je však podstatné: z důvodů popisovaných výše žákovské texty mohou sloužit jako validní reprezentace žákovského vnímání humoru v prostředí školy.

Jako analytický postup byla - vzhledem k povaze datového materiálu zvolena narativní analýza, tedy metoda určená k interpretaci textů, jež mají formu př́běhu. Riessmanová (2008, s. 53, s. 77) rozlišuje mezi tematickou a strukturální analýzou, kdy se tematická analýza koncentruje především na to, $c o$ je řečeno, zatímco strukturální analýza více na to, jak je to řečeno, tedy na způsob organizace vyprávění. Námi zvolený postup odpovídá tematické narativní analýze. Ta zahrnuje řadu technik známých i z jiných kvalitativních př́stupů, například otevřené kódování či kategorizace (srov. Švaříček \& Šed'ová et al., 2007, s. 211), rozdíl však spočívá v tom, že jednotlivé příběhy jsou udržovány souvislé a neporušené, není prováděna segmentace napříč prŕípady (Riessmanová, 2008, s. 11).

Páteř tohoto článku tvoří roztřídění sebraných textů podle tři různých situačních modů, $v$ jejichž rámci se učitel může stát objektem žákovského humoru. Zaprvé učitel může být bezděčně komický a nezáměrně vyvolávat smích žáků (kategorie komický učitel - zastoupena 16 texty). Zadruhé se může stát terčem připraveného žákovského žertu (kategorie napálený učitel - zastoupena 12 texty). A zatřetí může být záměrně vtipný a zcela cíleně povzbuzovat veselí ve tř́́dě (kategorie vtipný učitel - zastoupena 23 texty).

\section{Výsledky výzkumu}

V následujících pasážích postupně projdeme typické rysy textů zastupujících jednotlivé kategorie a pokusíme se interpretovat jejich obsah.

\subsection{Komický učitel}

Komické chování učitelů popisuje dvanáct žákovských textů. Zdrojem komiky je v drtivé většině případů chyba učitele, který něco poplete či nezvládne. Typickými zástupci této kategorie jsou vyprávění o tom, jak se učitelům vymykají z rukou výukové pomůcky. 


\section{Ukázka 1:}

Jednou, když naše třída chodila do nižšího ročníku, byla to třetí třída, se nám stala krásně veselá př́hoda.

Paní učitelka přišla do hodiny a jako pomůcku si vzala CD přehrávač. Chtěla nám pustit velice poučné "cédéčko“" Celá tř́da se těšila, že nemusí nic dělat, a že bude jen poslouchat „cédéčko". Paní učitelka si vše připravila a prehrávač chtěla zapnout. Jenže přehrávač mlčel. Celá tř́da i s paní učitelkou se divila: „jak to, že to nefunguje?“ paní učitelka ještě zkontrolovala přehrávač, ale nic nenašla.

Po chvilce zkoumání se ozval jeden nejmenovaný žák: „Paní učitelko, máte to $v$ zásuvce?" Najednou se celá trída začala smát. Proč? No protože to samozřejmě $v$ zásuvce nebylo. Zbytek hodiny už se nesl v rozesmáté atmosfére.

Toto mně přišlo jako nejsrandovnějši zážitek. To bylo neopakovatelné.

Každému bych tuto krásnou př́hodu př́l zažít.

(text č. 97, chlapec, 7. ročník ZŠ)

Jaký je princip komična $\mathrm{v}$ této ukázce? Jde o inkongruenci mezi jednáním učitele a společenskými požadavky kladenými na roli učitele. Z role učitele vyplývá, že by měl být za všech okolností kompetentnější než žáci, v této ukázce jsou to však žáci, kdo musí učitelce pomoci s tak banální záležitostí, jakou je zapojení přehrávače do zásuvky. Velmi podobnou situaci líčí jiný respondent $\mathrm{v}$ jiném textu:

\section{Ukázka 2:}

Každý učitel už někdy nejspíše dělal prezentaci, nebo cvičné cvičení v Activ-studiu. Je to velmi složité, ale když si ji stáhnete a pak ji neumíte otevř́t, je opravdu směšné. Vypadá to asi takto: Paní učitelka príide do třídy a zapne počítač. Najednou nastane problém v zapínání a už se to celé nese. Paní učitelka zapne interaktivní tabuli a my se jí pokoušíme radit. Radíme, radíme, paní učitelka nestíhá, nevnímá, najednou po nás začne řvát a má chut' počítač či notebook vyhodit z okna.

(text č. 122, chlapec, 7. ročník ZŠ)

Všimněme si úvodní věty z citované ukázky, která sugeruje, že každý učitel vytváŕí vlastní výukové materiály pro interaktivní tabuli. V kontextu tohoto tvrzení potom nabývá selhání učitelky při používání tabule nového významu jde o běžnou součást př́ipravy učitele na hodinu. Učitel, který techniku nezvládá, přípravu zanedbal, a tudíž se ocitá v postavení analogickém postavení žáka, který nemá domácí úkol nebo zapomněl učebnici. Toto je, domníváme se, klíčová funkce komických narací o chybách a omylech učitelů, totiž vytváření analogie mezi učitelskými a žákovskými prohřešky. Žáci se nesmějí jen učitelům, kteří přicházejí na vyučování nepřipraveni, ale také 
učitelům, kteří mají znečištěné či nedostatečně zahalující oblečení. ${ }^{4}$ To lze vnímat jako analogii k požadavku, aby žáci chodili do školy čistě a slušně oblečeni, který bývá na většině škol formulován ve školním řádu. Velmi vtipné potom žákům připadají ty situace, kdy učitel nějakým způsobem ztratí disciplínu požadovanou školou, např́klad usne na výchovném programu vedeným odborníky na protidrogovou prevenci (text č. 4) nebo nějakým jiným očividným způsobem poruší požadované normy chování, jak dokládá následující ukázka ze školního výletu do ZOO.

Ukázka 3:

...

Naše učitelka nám dala instrukce, jak se máme chovat. Denis se ptal, co je to instrukce. My se mu smáli, ale taky jsme to nevěděli!

Po př́chodu na Safary, které v ZOO je, jsme byli upozornění abychom nic nevyhazovali z okna safarybusu. Honza, který je drzej řekl že bus nemá žádný vokna, tak je to jedno. Paní učitelka si ho posadila vedle sebe. Jenže mu tak moc domlouvala a házela rukama až jí upadl z ruky náramek a př́mo do výběhu! To jsme nevydrželi a šíleně jsme se začali smát. Ošetřovatel podal náramek paní učitelce a ta pak celou dobu seděla s rukama v klíně! Denis tomu dodal, když řekl že paní učitelka by si měla přečíst inslekci, což spletl s instrukcí a zbytek výletu jsme se jen smáli. I paní učitelka.

(Text č. 44, dívka, 7. ročník ZŠ)

Komično obsažené $\mathrm{v}$ tomto př́běhu můžeme dobře interpretovat $\mathrm{v}$ duchu výše uvedené teze o analogii. Nejprve jsou na žáky uvaleny omezující požadavky, jejichž cizorodost je zdůrazněna tím, že jsou označeny slovem, které je pro žáky nesrozumitelné (instrukce). Učitelka provede další opatření k eliminaci narušení instrukcí, když si odmlouvajícího žáka Honzu posadí vedle sebe. Následně je to ovšem ona sama, kdo upustí náramek do výběhu, a tudíž přestoupí zadaná pravidla. Žákovský smích je zvoláním: jestliže ani učitelé nejsou dostatečně disciplinovaní, jak bychom to mohli dokázat my, žáci! Komika nalézaná v učitelských chybách a omylech je tudíž pro žáky úlevná, nebot' redukuje tenzi a frustraci vyvolávanou opresivními požadavky školy a učitelů. Dikce žákovských textů je různá: některé se k učitelům vyjadřují značně kriticky a de facto je obviňují z pokrytectví - vždyt' učitelé po žácích vyžadují perfektní výkony a sami je nepodávají. V jiných vyprávěních

4 V textu č. 103 popisuje respondentka komickou chybu tohoto druhu následovně: „Jednou do školy přišel náš učitel, a všichni se mu strašně smáli. Chudák celej den chodil a nic mu nepřišlo vtipné. Ale ono to bylo vtipné, měl rozepnutý př́klopec a menší flek na kalhotech." (text č. 103, dívka, 9. ročník ZŠ). 
(například v příběhu ze safari) zaznívá spíše tón společného spiklenectví vždyt' učitelé jsou také jenom lidé. Ambivalentní povaha komična a humoru dokonce umožňuje vyjádřit obě tyto emoce současně.

Komické situace předpokládají vždy určitou aktivitu na straně publika. Každá situace je komická jen do té míry, do jaké ji publikum jako komickou přečte. Lze si představit, že si skvrny na kalhotách učitele nikdo nevšimne, případně bude učitele litovat, že si poničil oblečení. Smích při chybě či přehmatu učitele tedy předpokládá aktivní percepci na straně žáků. Tato skutečnost se obzvlášt' zřetelně vynořuje ve chvíli, kdy se žáci baví tím, co učitel řekl či provedl, a to z toho důvodu, že jeho slovům či akci přičítají nový, učitelem nezamýšlený význam. Výsledkem takové významové subverze jsou na druhém stupni základní školy typicky obscénní či prostě sexuální obsahy.

\section{Ukázka 4:}

Vybrala sem si historku, která se stala v normální školní den. To se ale změnilo po tomto srandovním př́běhu. Stalo se to v páté vyučovací hodině. Bylo to pondělí, to si budu pamatovat napořád. Měly jsme zrovna hodinu češtiny, ze které máme naší tř́dní učitelku. Je docela fajn, ale ten den byla asi pěkně naštvaná. Nemohla nás vůbec utišit jak jsme se smáli. Zrovna jsme v češtině probírali litošku a četli nějaký článek o Indiánech. Taky jsme k tomu museli vypracovat otázky jako vždycky, a to je pěkná otrava. Ale to jsme ještě nevěděli, jak se dneska nasmějem. Já sem si myslela, že článek o Indiánech bude pěkná nuda. A to i všichni moji spolužáci. Ale našlo se tam několik vět, které nás všechny dostali. Zrovna tenhle den sem seděla se svou kámoškou Gabčou, před nama seděli Nikča a Kamča, to jsou taky moje kámošky. Všichni jsme se tomu hodně smáli. Jediný kdo se nesmál byla naše paní učitelka. Ona totiž nevěděla čemu se tak smějeme.

Když jsme ten článek začali číst, tak hned v první větě bylo: Šedý bobr vytasil svůj meč z pochvy a šel si do houští uř́znout klacek. Když jsme to slyšeli, tak jsme se neudrželi a začali se hrozně smát. A hlavně kluci se smáli. Nejvíc Tonda s Tadeášem. Naše učitelka jim vždycky ř́ká, že jsou to největši éra z naší tríldy a prej i možná z celý školy. A tak jsme se všichni pořád smáli a paní učitelka to furt nemohla pochopit. Až potom, když jsme narazilli i na další takové věty, tak to pochopila. Tak ukončila čtení, ale my se stejně furt smáli. A potom nám vysvětlovala, co to znamená, že šedý bobr je jméno a pochva je pouzdro na meč atd... Nakonec to vzdala, ale museli jsme ten článek opisovat celý. A to bylo fakt hrozný, protože byl hrozně dlouhý. Ale stejně jsme se celou dobu smáli a vždycky když si na to vzpomeneme, tak se smějeme.

(Text č. 58, dívka, 6. ročník)

Výrazy „bobr“, „pochva“, „meč“ či „klacek“ jsou žáky čteny jako označení pohlavních orgánů. Pohlavní orgány nejsou směšné samy o sobě, směšné 
je mluvit o nich ve výuce a slyšet jejich názvy z úst učitelky, která žákům marně vysvětluje „pravý smysl“ článku o indiánech. Principem tohoto druhu komična je průlom tabuizovaných obsahů do vyučování, literatura a sex jsou pro žáky základní školy zkrátka inkongruentní. Podle Wolfensteinové (1978) je ve slovní hře, tedy v přejmenování objektů či transformaci promluvy, vždy obsažen prvek agrese - transformovat něčí slova znamená transformovat jeho samého, narušit jeho sebepojetí a integritu. Prostřednictvím významové subverze děti přičítají učitelce lascivnost, hovoří přece o sexu $\mathrm{v}$ hodině literatury. Zároveň se v citovaném textu opakovaně zdůrazňuje, že učitelka neví, čemu se žáci smějí. To neznamená, že by učitelka neznala sexuální obsah daných slov, neví však, že jsou s ním obeznámeni i její žáci. $\mathrm{V}$ tomto typu subverzivního čtení je opět latentně přítomna kritika pokrytectví dospělých, jak lze demonstrovat též na ukázce 5.

\section{Ukázka 5:}

Jednoho dne při hodině angličtiny děcka pořád vrzala židlemi. Paní učitelka byla zrovna těhotná a hrozně ji to rozčilovalo. Pak se prostě neudržela a vyjela na nás: „Ještějednou vrznete a bude zle!"V tu chvíli jsme se začali smát, protože paní učitelka vrzala taky, ale vjiném slova smyslu. Po chvíli se s námi smála i paní učitelka a od té doby to vykládá každé třídě, kterou učí, i nám.

(Text č. 131, dívka, 7. Ročník)

Při transformovaném, významově subverzivním čtení učitelka, coby reprezentant dospělých, dětem zakazuje sex („vrzání“), ačkoli sama jej provozuje (důkazem toho je její těhotenství). Její chování, upozorňují žáci prostřednictvím svého smíchu, je pokrytecké. Opět jsme svědky komické ambivalence - v žákovském smíchu je obsažena hostilita, avšak komická forma ji maskuje a zjemňuje. Všimněme si, že paralelně s posměšným překrucováním promluvy žáci své vyučující projevují určitou uctivost, nebot' je v textu titulována jako „paní učitelka“ a celé vyprávění vrcholí konsenzuálně a přátelsky, když učitelka přistupuje na žákovský žert a sdílí jej s dětmi.

\subsection{Napálený učitel}

$\mathrm{V}$ předcházejícím oddíle byly prezentovány ty příběhy, $\mathrm{v}$ nichž se role žáků omezovala na aktivní percepci komických akcí učitele. Ve školním prostředí se však hojně vyskytují také situace, kdy žáci zesměšnění učitele sami vyvolají (spontánní žákovské vtípky) či dokonce plánovitě připraví (nástrahy na učitele). Takovýchto textů se mezi nasbíraným materiálem vyskytlo třicet, $\mathrm{z}$ toho jedenáct reprezentovalo spontánní vtípky, devatenáct nástrahy na 
učitele.

Spontánní žákovské vtípky tvoří situační humor, jehož podstatou je nějaká forma žákovské nedisciplinovanosti či drzosti. Může jít o prostořekou průpovídku jako například v textu č. 21, v němž autorka líćí průběh inspekce ve škole, $v$ jejímž průběhu vypadne proud a vypnou se počítače. Jeden ze žáků v té chvíli k př́ítomnému inspektorovi poznamená: „To je tady naprosto normální." Vtipná průpovídka je v této chvíli de facto trestem pro učitelku, která se podílela na připravování kamufláže před inspekcí, jak sugeruje úryvek z textu zachycený v ukázce 6 .

\section{Ukázka 6:}

...

Už měsíc dopředu jsme museli ve všech třídách, jak se lidověř́ká „pořádněgruntovat". Najednou se vyklízeli staré skř́ině a stěhovali se pryč. Pokud museli skř́ně zůstat na svém místě, oblepovali se vybranými, nejhezčími výkresy. Dříve když jsme si chtěli některé výkresy vystavit, tak jsme nesměli, proto mě to príjde $k$ smíchu, jak se kvůli inspekci dokázalo mnoho věcí zlepšit, samozřejmě že k lepšímu.

Každý učitel i učitelka upozorňovali v každé tř́ídě, jak se máme chovat. Dokonce jsme dostali, od některých učitelů otázky a odpovědi, kteréjsme se měli doma naučit, aby až tam bude inspekce, jsme se hlásili a vypadali, že jsme vzdělaní žáci a né žádní hlupáci.

Učitelé i učitelky změnili své chování k nám, tak o 50 \% k lepšímu. Měli asi strach, aby nevypadali jako bručouni a proto se každý usmíval a snažil se látku vysvěttit, tak aby to pochopili opravdu všichni. Uměli k tomu přidat př́klady ze života a nám se lépe látka učila i pamatovala. Velká škoda, že jim to nevydrželo déle než do konce inspekce, která tam pobyla týden.

(Text č. 21, dívka, 9. ročník)

Humorný nesoulad mezi očekáváními učitelů a chováním žáků je zde líčen v duchu sociální korekce (viz Bergson, 1994), žákovský výsměch má přimět učitele, aby se zamysleli nad svým chováním a změnili ho (například se více snažili zaujmout žáky i v běžných hodinách).

Do kategorie spontánních žákovských vtípků spadají příhody, kdy žákyně vtrhne do třídy s pokřikem: „Zase máme toho plešouna," zatímco dotyčný učitel je již v místnosti přítomen (text č. 62), stejně jako bučení v hodině (text č. 78) či oslovování učitelů přezdívkami (text č. 9). Kromě čistě verbálního humoru sem spadá i tělesná neverbální komika tak, jak je zachycena např́íklad v ukázce 7. 


\section{Ukázka 7:}

Když jsme byli na hudební výchově u paní učitelky, tak se stala taková hrozně legrační událost. Můj spolužák Jakub šel vyhodit odstřižky od hudebních skladatelư, vzal i ty moje a Ančiny. Když šel zpátky tak si sednul na židli paní učitelky. Paní učitelka zrovna byla u mladší třídy, se kterou jsme spojeni. Byla tam, aby jim pomohla s pískáním na flétnu. David měl ale špatnou flétnu, tak se to řešilo. Mezi tím si Jakub hověl na židli. David s Čeňkem to zkusili zahrát ještě jednou. Když dohráli, paní učitelka se rychle otočila. Jakub vystřelil jako torpédo ze židle. Skoro celá třída se tomu chechtala a Jakub taky. Paní učitelka se zeptala, proč se směje a Jakub jí odpověděl: „Byl jsem jenom vyhodit papírky od těch skladatelů.“ Načež se zase skoro celá třída začala smát.

(Text č. 90, dívka, 6. ročník)

Co je v této ukázce směšné, je záměna rolí učitele a žáka, která se realizuje skrze obsazení učitelského prostoru. Opět jsme svědky nevědomosti učitelky o tom, co se přihodilo, která posiluje komický účinek Jakubovy akce. Podobná nevědomost je popisována i v ukázce 8 , kde žák provádí opičky za zády učitele, přičemž komickým principem je nepřiměřená blízkost mezi žákem a učitelem.

\section{Ukázka 8:}

Jeden žák z mé třídy, Ondřej B., je průměrný žák. Vyvádí kdejaké voloviny, samý průser. Rád ode mně opisuje, takže když je písemka, sedím u něj aby měl z toho dobrý pocit (myslí si, že mu udělám celou písemku, ale nanejvýš mu řeknu dvě, tři odpovědi). I tento den jsme měli psát písemku a já byl násilím vtažen do jeho spárů. Nemohl jsem ucuknout.

Jakmile usedle učitel na židli, bylo nám jasné, že učitel žádní písemky nemá. ... Dělali jsme samostatnou práci (avšak polovina tř́́dy skupinovou) a měli jsme ji ke konci hodiny ukázat učiteli. Můj dobrý spolužák ji šel také ukázat. Ale protože byl pan učitel zaneprázdněný s jiným chlapcem, začal se můj spolužák nudit. Nejspíš dostal na něco chut', a tak natáhl jazyk k zády sedícímu učiteli. On však ucukl a záhy měl olíznutou pleš. Podíval se nahoru, ale Ondřej v tom okamžiku se otočil a dělal, že pozoruje cosi na tabuli, tak si pan učitel setřel hlavu a dál se věnoval druhým.

Ondra šel za mnou do lavice s mikinou v puse. Musel si párkrát odplivnout a pak se vzpamatoval. Ti co seděli v lavicích, měli zaslzené oči.

Pan učitel netušíc, co se děje jen kroutil hlavou.

(text č. 102, chlapec, 9. ročník)

Spontánní žákovský humor zaměřený na učitele pokrývá širokou paletu situací, jejichž podstatou je vždy překračování vymezených hranic - žáci říkají, co se nemá, používají zakázané předměty, vydávají zapovězené zvuky, 
obsazují místa, která jim nepřísluší a podobně. Společným rysem těchto druhů žertů je jistá těkavost: objeví se z ničeho nic, trvají krátce a rychle se vyčerpají. Fungují jako chvilkové osvěžení, vytržení z pracovního stereotypu a soustředění. Tento typ žertů na sebe často berou trrídní klauni, kteří podle Ziva (2010) vystupují jako reprezentanti žákovské skupiny a zároveň absorbují případný trest. Jinými slovy, klauni mají odvahu dělat to, co by rádi dělali i ostatní, a navíc jsou ochotni se za to nechat od učitele potrestat.

Vedle spontánního humoru se však v nasbíraném materiálu objevily také žerty, které jsou plánované a mají charakter určité léčky na učitele. Pro všechny tyto př́běhy je charakteristická manipulace s fyzickými předměty, které žáci nějakým způsobem nastraží tak, aby vytvořily návnadu nebo přímo past na učitele. Některé z těchto vtipů jsou poměrně nevinné - žáci například vloží umělého pavouka do zásuvky učitelského stolku (text č. 110), mezi křídy vpašují menstruační tampon (text č. 129), nebo podstrčí učitelce na židli smradlavý pytlík (text č. 37). Takovýto typ léčky popisuje ukázka 9.

\section{Ukázka 9:}

Jednoho chladného unuděného zimního dne, jsme se ze svým spolulavicárem Michalem přšserně nudili a nejen my, celá tř́́da na tom byla stejně. Venku počasí moc neprálo, hodiny se zdály jako by trvaly celý den a nechtěly skončit, zachtělo se mi kontrolovat oční víčka zevnitř, ale najednou v tom víru nudy mi blesknul hlavou podlý a záludný nápad. Musíme se nějak odreagovat, zasmát se, jinak asi umřu nudou. Stejně jednou umřu, ale dneska se mi do umírání moc nechtělo - a jak jinak se zasmát než si z někoho udělat legraci, nechtěl jsem nikoho moc ztrapnit. Jenom takovou nevinou srandu. Přemýšlel jsem celou hodinu, ale nic mě nenapadlo a takjsem do svého nápadu zasvětil polospícího Michala. Dumali jsme nad tím půlku přestávky a pořád nic. Najednou mi v kapse zabzučel telefon - SMS - a ejhle, nápad byl na světě. Když jsem ve škole, mám na telefonu vypnuté zvuky a zapnuté jenom vibrace. Když mně přišla ta SMS, tak jsem si vzpomněl na nestarý vtípek, který jsme uskutečnili v hodině němčiny. Na učitelskou židli jsme tehdy přilepili zespodu telefon s vibracemi a volali jsme na něj, když naše němčinářka na té židli seděla. Bohužel toto moc nevyšlo, vibrace byly slabé, a židle moc polstrovaná. Ale stůl je přece tvrdý a je to na něm krásně slyšet, pověděl jsem to Michalovi a ten řekl "tak jo". Koukli jsme na rozvrh hodin a řekli si, že nejlepší obětí bude naše češtinářka. Vzali jsme lepící pásku, můj telefon a přilepili ho zespod učitelského stolu. Proběhla zkouška kde vibrace z mého telefonu byly hlučnější než jsme čekali. Nachystali jsme si věci, sedli si, připravily druhý telefon a číhali, než príijde obět'. Učitelka vešla do tř́ldy tř́́da se znuděně zvedla a zase se znuděně posadila. Učitelka zaujala místo a začala do nás pérovat nové učivo ČJ. My s Michalem jsme vyčkávali, až přijde ten správný čas. Ten nastal, když jsme měli sami dělat cvičení z učebnice. Ve tř́dě bylo ticho, 
ticho a najednou se začaly ozývat zvuky, jak když zapnete vibrátor. Učitelka to nějak moc nevnímala, ale třída se válela smíchy po zemi. Rozkřiklo se to hodně rychle a všichni na můj telefon začali volat. Učitelka to ovšem pořád zasklívala a tak jsme si s Michalem řekli, že to vyšlo tak z půlky. Najednou jako kdyby všichni ožili a začali se bavit jako každý krásný den. Všechno bylo najednou OK, třída se bavila, telefon brněl, učitelka nechápala. To ale není konec! Cca 15 minutách se učitelka naštvala a vykřikla - „Nechte toho, bolí mě hlava tady z toho vrtání a do toho ještě kecáte!“ Tímto to učitelka takzvaně totálně zabila. Všichni jsme málem umřeli smíchy, ani já a Michal jsme nečekali, že to bude až takový „Hardcore“. Učitelka jenom nechápavě kroutila hlavou a posadila se. já a Michal jsme byli za frajery a paní učitelka si počkala, až se všichni vrátí do normálního provozu a začala vysvětlovat dál za hlučného brnění telefonu (vlastně vrtačky).

(text č. 49, chlapec, 9. ročník)

Citovaná ukázka dobře vykresluje plánovitost popisovaného žertu. Nad tím, co a komu provést, žáci dlouze „dumají“. Všimneme si slovníku, který evokuje počínání lovce kladoucího past - žáci vybírají „nejlepší obět'“, „„číhají, než přijde“ a pak „vyčkávají, až přijde ten správný čas“. Jestliže jsme jako latentní funkci subverzivního čtení učitelských výroků přiznali skrytý útok na učitele, v případě léček jde již o útok zcela zřejmý. Je to útok hravý, který není nijak hrozivý, autor textu výslovně uvádí, že mělo jít o „nevinnou srandu“, při níž „nechtěl nikoho moc ztrapnit“. V tomto typu incidentů se jasně zrcadlí dvojznačnost humoru. Na jedné straně nepochybně jde o útok na vybranou obět', na druhou stranu se tento útok odehrává v humorném modu, tudíž zároveň je i není skutečný. Aktéři - vidíme, že se prostřednictvím prozvánění přilepeného mobilu aktivně zapojuje větší část třídy - se nemusí cítit provinile, způsob, jímž kanalizují své nepříjemné prožitky (smrtící nudu) a vyzískávají z nich příjemné emoce (zábavu), je přijatelný, nebot' je interpretován jako humorný. Nuda obecně je patrně hlavní motivací žákovských pokusů o humor, přemáhání nudy je vnímáno jako legitimní důvod pro různé typy žertů, jak je z ukázky 9 patrné („musíme se nějak odreagovat, zasmát se, jinak asi umřu nudou").

Léčky na učitele se neomezují pouze na nevinné žerty. Některé texty popisují takové incidenty, jejichž cílem není jen v hravém modu zaútočit, ale přímo způsobit nějakou újmu či škodu. Ačkoli je i toto jednání žáky chápáno jako humorné (o tom svědčí skutečnost, že je jako takové popisují ve svých textech), tyto léčky důsledně a se zjevnou zlomyslností sledují svůj cíl: žáci chtějí své učitele vidět pokořené. V textu č. 11 například natřou učitelce židli 
lepidlem, ačkoli vědí, že dojde k poškození její sukně. Autor přitom uvádí, že jde o „pomstu za neplánovanou písemku“. Zde už vidíme logiku vendety, žáci se učitelům mstí za příkoří, která jim způsobují. Nejtypičtější akcí tohoto druhu je nějaký způsob manipulace se dveřmi do třídy; těm je uvolněna klika, jsou vysazeny z pantů nebo je na ně nainstalován nějaký předmět (pokud možno mokrý) tak, aby otevření dveř́i způsobilo jeho pád.

\section{Ukázka 10:}

...

Plán byl následující: Vysypali jsme odpadkový koš do umyvadla, celý ho napustili vodou, ke dveř́m jsme prirazili židli, na opěrátko postavili odpadkový koš plný vody a zapřeli ho o dveře a potom už jsme jen čekali, až přijde náš „oblíbený“ učitel výtvarné výchovy... a tohle všechno jsme zvládli za neuvěritelných 10 minut.

Zazvonilo na hodinu, všichni si nachystali věci, vzorně si sedli do lavic a bylo hrobové ticho, jako nikdy predtím. Během minuty se rozletěly dveře a odpadkový koš plný vody polil našeho výtvarkáře od hlavy až $k$ patě. Ten celý zrudl a začal na nás tak hlasitě řvát, že za chvíli přiběhla i naše ředitelka v lodičkách a v kostýmku, ve kterém jde vidět snad úplně všechno a začala zjištovat, co se stalo.

Politý a strašně naštvaný výtvarkář hned běžel pro naši třídní a ta se k nám do třídy přiř́tila takovou rychlostí, že si nevšimla polité podlahy, takže uklouzla a rozplácla se přímo v té kaluži vody. Chvíli jí to trvalo, ale zvedla se a byla snad ještě víc mokrá než pan učitel. Celá tř́ida se mohla uřezat smíchy a tento pohled nevydržela ani paní reditelka a propukla v záchvat smíchu.

(Text č. 1, dívka, 9. ročník)

To, co se u dveří odehrává, je bitva o vstupní prostor. Zahrazením dveří žáci dávají najevo, že teritorium třídy není pro učitele přístupné. Samožrejmě počítají s tím, že učitel nakonec do třídy pronikne, obstrukce, které přitom musí překonat, jsou však chvilkovým triumfem žákovské skupiny. Humorným principem je zde převrácením obvyklých školních pravidel, podle nichž rozmístění aktérů v prostoru určuje učitel (například sestavením zasedacího pořádku) a žáci jsou povinni se mu podřídit.

\section{Ukázka 11:}

Byla jednou jedna základní škola a na ní učil učitel, který když byl nasraný na svou třídu (což bylo skoro pořád, protože ta třída byla hodně,,veselá"), tak velmi rád třískal dveřmi. Jednoho dne si jeden velmi konstruktivní žák této tř́́dy všiml, že učitel je zase nasraný, z toho vydedukoval, že kdy príjde do třídy, tak opět bouchne dveřmi. Onen žák tedy povysadil dveře z pantů, učitel dorazil do třídy, tř́sknul dveřmi a zbytek si určitě domyslíte. Když došel a chyt za kliku tak se celý dveře vyvalili a celý to spadlo. 
Byla to děsná rána a všichni se lekli. Holky začly pištět a my sme se začali řechtat jako koně. On začal řvát na celou tř́d u kdo to byl, at'se hned přizná ale všichni sme se jenom řechtali. Potom došla učitelka $z$ vedlejší tř́dy a snažila se ty dveře s ním nasadit spátky. Ale vůbec jim to nešlo. Pořád kolem toho chodili a vo něčem se radili. Pak šli pro školníka. Ten konstruktivní žák šel s ještě jedním ty dveře nasadit a pak jsme dělali jakože nic. Ale holky se pořád smály a tím to celé provalily.

Př́ště se prej zkusí jenom namazat klika.

(Text č. 63, chlapec, 8. ročník)

V ukázce 11 se opět vyjevuje logika odplaty - učitel je potrestán za své tř́skání dveřmi. Zároveň se zde žákovská aktivita neomezuje jen na vytvoření bariéry na vstupu, ale je zde též přítomna lišácká oprava dveří bez vědomí učitele tak, aby si tento myslel, že celý problém způsobil on sám svou neopatrnou a nekompetentní manipulací $s$ dveřmi. Pokud by žákům jejich lest vyšla a zůstala nerozpoznána, ocitl by se učitel v pozici člověka, který není schopen včas zahájit výuku (má pozdní příchod) a navíc poškozuje školní majetek. Jde znovu o mechanismus analogie mezi žákovskými a učitelskými prohřešky, avšak zde jsme svědky toho, jak žáci aktivně konstruují situaci, která tuto analogii umožní.

\subsection{Vtipný učitel}

Učitelé však zdaleka nejsou pouze pasivními figurkami, jimž se žáci smějí, aniž by to oni sami mohli nějak ovlivnit. Naopak, učitelé jsou často iniciátory humorných situací a žákovský smích využívají ke svým účelům. Lze říci, že v těchto př́ípadech se žáci ani tak nesmějí učitelům (jak je uvedeno v názvu tohoto článku), jako spíše s učiteli. Naše data o vtipném jednání učitelů se rozpadají do dvou kategorií - první z nich tvoří humor, který má primárně pedagogickou funkci, druhou potom humor, který má primárně funkci mocenskou.

Pedagogický humor chápeme $\mathrm{v}$ tom smyslu, že prostřednictvím vtipu či legrace chce učitel dosáhnout zvýšení pozornosti žáků či lepšího pochopení probírané látky. Tento typ humoru reprezentují například texty věnované psaní humorně travestovaných pohádek v hodině slohu (text č. 99), učitelem organizované hře na mafii $v$ anglickém jazyku (text č. 99) či vtipnému vysvětlování fenoménu zemětřesení. 


\section{Ukázka 12:}

...

Jednou jsme měli suplování na český jazyk a přišel pan učitel, který nás učí zeměpis. Řekl: „Dnes budeme mít zeměpis a budeme se učit, jak vzniká zemětřesení." Pan učitel chodil po třídě a vysvětloval nám, jak vzniká zemětřesení. Vysvětloval nám to asi 30 minut a nikdo to nechápal. Pan profesor se naštval, vyletěl ze třídy a vrátil se asi za tři minuty. Přišel se sýrem Apetito. Všichni na něj koukali. Řekl: „No tak když jste to nepochopili, tak vám to musím vysvětlit lépe. Tady ten sýr je jako litosférická deska! A ted' koukejte!“ Vzal sýr, rozmáčkl ho a řekl: „Takhle vzniká zemětřesení!“ Všichni se začali smát.

...

(Text č. 32, dívka, 6. ročník)

Principem humoru je v této ukázce použití neadekvátní pomůcky - sýra namísto obvyklých didaktických modelů. Podstatou pedagogického humoru je používání neobvyklých, inkongruentních stimulů. Učitel typicky těží z momentu překvapení, někdy až šoku žáků. To lze dobře doložit na následující ukázce.

\section{Ukázka 13:}

Při hodině češtiny, když jsme byli v šesté třídě jsme si s paní učitelkou opakovali vyjmenovaná slova. Při opakování slov po M nám všem jedna spolužačka tvrdila, že mít mozek nemůže se psát s měkým I po M. Jelikož boj mezi spolužačkou XY a paní učitelkou trval už přes 10 minut, začali docela milé profesorce povolovat nervi. Snažila se jí vysvětlit, jaký je v tom rozdíl. Nakonec se naše kantorka rozhodla, přejít na činy místo vysvětlování. Vzala houbu na tabuli, chytla spolužačku XY za ruku a vedla ji k umyvadlu. Najednou u umyvadla spolužačce XY řekla: „Tak teda vem si houbu a UMYJ si mozek, když si myslíš, že to jde." Spolužačka se nechápavě podívala a najednou pochopila jaký je rozdíl v MÍT MOZEK X MÝT MOZEK.

Po této př́hodě už nikdy nezapomenu na rozdíl mezi slovy MÍT X MÝT, myslím, že i mí spolužáci si toto budou taky pamatovat a už nikdy v tomto nikdo z nás neudělá chybu.

(Text č. 28, dívka, 9. ročník)

Jak uvádí autorka textu citovaného v ukázce 13, všichni přítomní žáci si po tomto dramatickém výkladu budou probíraný jev pamatovat. Důvodem je nepochybně neobvyklost celé situace, inkongruentní představa mozku omývaného vodou z vodovodu, ale také silný emocionální náboj popisované události. Je v ní totiž patrný prvek agrese učitelky vůči žákyni. Není přípustné, aby učitelka v seriózním modu ostře kritizovala nadánía kognitivní schopnosti 
žákyně, proto tak činí v modu humorném. Tím se dostáváme ke skutečnosti, že to nejsou pouze žáci, kdo využívají humor jako zbraň, at' už útočnou, nebo obrannou.

Většina učitelských vtipů zaznamenaných v sebraných žákovských textech totiž nesleduje primárně pedagogické cíle, nýbrž se týká vztahového a mocenského vyjednávání mezi učiteli a žáky. Vtipní učitelé používají humor za účelem převzetí kontroly nad situací ve třídě, jeho prostřednictvím vyjadřují a posilují své dominantní postavení.

\section{Ukázka 14:}

U nás ve tř́dě je plno srandy, ale bohužel ne s děvčaty, takže si vystačíme sami kluci.

Největší sranda je s našim panem učitelem Zeměpisu. Dřive než nám něco vysvětlí, tak nás trochu vyděsí, ale vtipně. Jeho oblíbená věta: „V̌̌echno je z ropy!!!“ Jednou jsme ho vyděsili my. Na tabuli jsme o přestávce namalovali svalnatého chlapa s kosí hlavou. Když pak v hodině otevřel tabuli, řekl: „Zase takové svaly nemám!“ Vůbec se nezlobil, a to že mohl, jmenuje se totiž Pavel KOS!

(text č. 10, chlapec, 6. ročník)

V ukázce 14 učitel v hodině najde na tabuli svoji karikaturu, reaguje však sebeironickým humorem, což žáci kvitují s povděkem („vůbec se nezlobil, a to že mohl“). Humor je jedním z nástrojů, jimiž lze dosáhnout mocenské převahy. Jestliže se žáci smějí záměrným vtipům učitele (nikoli komickým přehmatům), znamená to, že $\mathrm{v}$ dané chvíli je to on, kdo vytvář́i definici situace, a žáci jsou ti, kdo na ni přistupují. Naopak pokud se celé třída směje žákovskému žertu, je to iniciátor tohoto žertu, kdo ovládá a definuje situaci.

Případy převzetí kontroly nad situací ve třídě pomocí humoru mají proto po komunikační stránce obvykle podobu symetrické eskalace (Watzlawick \& Beavin-Bavelasová, 2000, s. 92). Žákovský vtip přebíjí učitel vtipem silnějšího kalibru. $V$ textu č. 8 žáci o přestávce kreslí na tabuli komické malůvky, načež přichází na suplování obávaná učitelka. Ta, namísto aby se rozčílila, že tabule není vzorně čistá, si z obrázku dělá legraci, ptá se dětí, zda jde o portrét jejich češtinářky a zda je po plastické operaci. Celá třída se „válí smíchem pod lavicí". Co je zdrojem humoru v této př́hodě? Inkongruence spočívá v neočekávaném chování učitelky, která nehájí barvy učitelského sboru a namísto toho vytváří koalici se žáky. Ti, kteří se smějí SPOLU, mezi sebou vytvářejí kulturní pouto, naopak ten, KOMU se smějí, je postaven mimo skupinu, stává se outsiderem. Citovaný text končí příznačně: „Už se těším až 
zase bude učitelka na češtinu nemocná, abychom měli ji [suplující učitelku] na suplování a opět se tak výborně bavili.“

Jak jsme ukázali výše, žákovské vtipy jsou někdy drsné a vulgární. Při symetrických eskalacích potom dochází k tomu, že učitelé drsnost či vulgaritu stupňují, jak dokládá ukázka 15.

\section{Ukázka 15:}

Každý měl ř́íct nějaké podstatnéjméno s tím, že někdo jej přijde napsat na tabuli. Do hluku slov najednou zaznělo slovo "hovínko" na to hned paní zástupkyně urychleně zareagovala a vyzvala Pepu k tabuli at' vyskloňuje slovo „hovno“. Jelikož Pepa řekl slovo „hovínko" a paní zástupkyně slyšela „hovno" nastala hádka. Neústupná paní zástupkyně na konec rozhodla, že se stejně bude skloňovat „hovno“. Pepa začal psát: 1. pád - hovno, 2. pád - hovna, 3. pád - hovnu, 4. pád - hovno, 5. pád - hovno! 6. pád - hovnu, 7. pád-hovnem.

Po dokončení své „písemné práce“ ji Pepa musel nahlas a zřetelně přečíst. Všichni se smály, dokonce tuto situaci někteři natáčeli. To se ale paní zástupkyni nezdálo a natočení zakázala, ale... vždycky se to nějak udělá... Myslím, že ještě dnes by jsme u někoho toto komické video našli. Paní zástupkyně se také velice smála, ale nakonec Pepu pochválila za dobře vypracovanou práci.

(text č. 51, dívka, 9. ročník)

V citované ukázce se učitelka obnovuje kázeň ve třídě zaujetím dominantní pozice. Žák, který ve zvukovém šumu tvořeném hlasy jiných žáků vykřikl slovo "hovínko“, je následně nucen před celou třídou opakovaně exponovat toto slovo v nezdrobnělé podobě. Pronést vulgární slovo ve vyučování je sice pro žáky znakem frajerství a povznesenosti nad školní normy, ovšem jen v tom případě, že tak žák činí z vlastní vůle. V ukázce 15 je to však učitelka, kdo žákovi nařizuje, aby se takto choval, demonstrace její převahy je tudíž umocněna, nebot' nad žákem vítězí jeho vlastními zbraněmi. Humorný princip je zde zřejmý - je směšné, pokud učitelka žáka nabádá k vulgarismům místo, aby jim zamezovala. Zároveň si povšimněme transformace, $\mathrm{k}$ níž v ukázce dochází: žák chce být vtipný, ale ve výsledku je pouze komický. Jeho původním záměrem bylo přivést do rozpaků a potenciálně zesměšnit učitelku, nakonec se však celá třída směje jemu.

V ukázce 15 tedy učitelka transformuje vtip žáka na komično. Vtipní učitelé, kteří jsou schopni pomocí humoru převzít kontrolu nad situací ve tř́dě, ovládají různé druhy takovýchto transformací. V ukázce 16 učitel pohotově 
provádí transformaci opačnou oproti ukázce 15: komično pramenící z vlastního směšného oblečení proměňuje na vtip.

\section{Ukázka 16:}

Probíhala normální hodina angličtiny, při kteréjsme probírali minulý čas. Pan učitel netradičně oblečen $v$ teplácích (protože měl preded touto hodinou kluky na tělocvik) nám celou tabuli popsal jedním ze svých nepochopitelných výkladů, který $k$ tomu všemu anglicky nahlas komentoval. Vủbec jsme nevěděli, o čem mluví, ale většinou to takhle probíhalo každou hodinu, tak jsme mlčeli a poslušně každé slovo opsali. Sledovala jsem jen tabuli, proto mi přišlo divné, že se moje kamarádka potichu směje. Podívala jsem se na ni a ptala se, co se děje. Řekla mi, at'se podívám na pana učitele. Chvíli jsem ho pozorovala a neviděla na něm nic zvláštního, pak mě ale upoutali jeho kalhoty. Měl je totiž naopak, a to dost viditelně. Kamarádka to mezitím stihla rozhlásit dalším spolužákưm. Najednou to věděla celá třída a taky to dávala dost najevo. Pan učitel přerušil svoje vypravování a ptal se nás, co se děje. Jeden velmi aktivní kluk se hned přihlásil. „Máte opačně kalhoty.“ Celá trída se smála velmi hlasitě, ale to pana učitele neodradilo od toho, co udělal dál. Vylezl si na stupínek, rozvázal si boty a tepláky sundal. Obrátil je a zkontroloval, jestli si je už ted' nasazuje dobře. Znovu se oblékl, zavázal boty a pokračoval ve výkladu. Všichni jsme byli vyděšení a pořád se smáli. Pan učitel, jakoby se nic nestalo, nám ještě na závěr zapsal pár slovíček, jako to vždycky dělal. Mezi nimi byla i tahle dvě: hloupý smích, obrácené kalhoty.

Další den jsme angličtinu měli znovu. Očekávali jsme, že zase prožijeme nějaký zážitek, že se zasmějeme. Tentokrát se smál nanejvýs pan učitel, který si pro nás něco nachystal. Psali jsme písemku na překlad, kde se obě slovíčka ze včerejší hodiny objevila. Musím říct, že ten smích nás přešel hned.

Možná se to zdá normální, ale na tohle opravdu nikdy nezapomenu.

(Text č. 130, dívka, 9. ročník)

Učitel v ukázce aspiruje na to, aby byl zařazen do kategorie komický učitel. Třída se mu zpočátku směje, aniž by věděl proč. On však okamžitě přechází do protiútoku a ptá se dětí, čemu se smějí. Po zjištění důvodu nepřechází do defenzivy, naopak vylézá na stupínek a pojímá nápravu svého zevnějšku jako veřejné představení. Žáci jsou zděšení a zároveň se smějí, nebot’ obnažený učitel je ve škole nepochybně inkongruentní úkaz. Opět jsme svědky toho, jak učitel přebíjí žákovský posměch silnějším vtipem. Svým kouskem žákům sděluje: nevadí mi, že jste mě viděli s obrácenými kalhotami, je mi totiž jedno i to, když mě uvidíte bez kalhot. Vše korunuje tím, když slovíčka připomínající vlastní pochybení zadá žákům k pamětnímu osvojení a v příští hodině je zkouší (namísto snahy zahladit celou záležitost). Celým svým počínáním 
demonstruje mocenskou převahu, ukazuje, že je imunní vůči žákovskému posměchu a že je tím, kdo plně kontroluje dění ve třídě.

\section{Závěr}

V tomto článku jsme analyzovali žákovská písemná vyprávění s cílem dozvědět se něco o podobách a funkcích školního humoru zaměřeného na osobu učitele. $V$ různých typech humorných příhod jsme se snažili identifikovat, co je na učitelích - viděno žákovskýma očima - vlastně směšné. Z podstaty humoru jde vždy o určitý typ inkongruence, $v$ případě našich dat o rozpor mezi tím, co se od jednotlivých aktérů z hlediska jejich institucionálně definovaných rolí očekává, a co v dané chvíli reálně činí. Od učitele se očekává, že bude kompetentní, dominantní, emocionálně vyrovnaný a bude reprezentovat oficiální společenské hodnoty. Součástí žákovské role je disciplinovanost, zdvořilost a ochota podrobit se učiteli. Kromě toho se od obou stran v prostředí školy očekává, že potlačí případné projevy vlastní sexuality. Jakékoli odchylky od takto nastavených očekávání se mohou stát zdrojem humoru.

Páteří tohoto textu bylo rozčlenění humorných situací, jejichž objektem jsou učitelé, do tří modů (komický učitel, napálený učitel, vtipný učitel). V každém z těchto modů lze identifikovat určité dominující principy, na nichž jsou humorné incidenty vystavěny. Tyto principy schematicky zachycuje tabulka 1.

Tabulka 1

Situační mody a principy humoru

\begin{tabular}{llll}
\hline Situační modus & Komický učitel & Napálený učitel & Vtipný učitel \\
\hline Klíčové principy & Upozornění na chybu & Překračování & Pedagogický užitek. \\
& učitele. & stanovených hranic ze & Převzetí mocenské \\
& $\begin{array}{l}\text { Průlom tabuizovaných } \\
\text { obsahů do výuky. }\end{array}$ & strany žáků. & Léčka na učitele. \\
& & Trest pro učitele. & \\
\hline
\end{tabular}

Nad těmito dílčími principy se klenou dva zastřešující. První z těchto principů spočívá v upozornění na to, že učitel neučí žáky předepsané obsahy či tak nečiní předepsaným způsobem. Pod tento princip můžeme zahrnout situace, kdy učitelé předkládají žákům nestandardní úlohy (skloňovat sprosté slovo), používají nestandardní pomůcky (tavený sýr), jsou nestandardně 
oblečeni a podobně. Druhý zastřešující princip představuje ještě extrémnější převrácení očekávaného řádu, totiž skutečnost, že žáci učí učitele. Například mu pomáhají $\mathrm{s}$ audiovizuální technikou anebo mu prostřednictvím léčky a trestu ukazují,jakému chování by se propř́iště měl vyhnout. V analyzovaných textech se totiž poměrně hojně vyskytovala konstatování, že po žákovském žertíku si př́ště dá učitel pozor, kam si sedá, jakou křídu si bere, jestli bouchá, nebo nebouchá dveřmi a podobě. Tento typ humoru směřuje $\mathrm{k}$ tomu, že žáci získávají do určité míry převahu nad učiteli, a tudíž si přisvojují i některá jejich privilegia (například poučovat a trestat).

Naopak princip nestandardních obsahů a prostředků vede obvykle k posílení převahy učitele. Vtipný učitel tř́́du ovládá, nebot' pokud se žáci smějí jeho vtipům, sdílejí jeho definici situace. Připomeňme, že jednou $\mathrm{z}$ funkcí humoru je vytváření koalice mezi těmi, kteří se smějí společně. V některých z prezentovaných ukázek se smáli žáci společně s učitelem, $v$ jiných se smáli pouze žáci a učitel nikoli. Rovněž bychom našli př́íklady, kdy se směje pouze část tř́idy, nebo se třída spolu s učitelem směje jinému učiteli či jiné třídě. Ve všech těchto případech smích vyznačuje hranici komunity, determinuje, kdo je uvnitř, a kdo zůstává venku. Z tohoto hlediska lze dobře rozumět učitelům, kteří v modu napáleného učitele reagují tak, že se připojí ke smíchu svých žáků a přistoupí na to, že jsou vnímáni jako objekt humoru. Jestliže Woods (1983, s. 112) uvádí, že humor může ve škole sloužit jako nástroj rezistence či naopak facilitace, můžeme upřesnit, že humor slouží jako nástroj rezistence a facilitace současně. Vůči těm, kdo se nesmějí, jde o rezistenci, vztahy mezi těmi, kteří se smějí, jsou naopak facilitovány.

Přestože žáci i učitel při humorných incidentech prožívají př́ijemné a uvolňující emoce, naše data v souladu s tezemi některých teorií (Freud, 1995; Wolfenstein, 1978) ukazují, že značná část zaznamenaného humoru obsahuje motiv hostility či agrese, a to jak ze strany žáků, tak ze strany učitelů. Humor tedy nemůžeme automaticky vnímat jako něco automaticky pozitivního a veskrze př́iemného, jde o fenomén, který je ze své podstaty ambivalentní. Zároveň však nelze humor ve škole pro jeho latentní agresivitu zavrhovat. Jednak frustrace, napětí a hostilita ve vztazích mezi učiteli a žáky prostě existují a jejich vyjádření prostřednictvím humoru (leckdy ve velmi subtilní podobě) je přijatelnější než jejich vybití v přímém, vážně míněném střetu. Rezistence je navíc nástrojem utváření vlastní identity, což je vývojový úkol, který žáci druhého stupně postupně začínají řešit. Abychom si ujasnili, kým jsme, musíme se vymezit vůči ostatním. Ve starším školním věku se jedná 
do značné míry o procesy skupinové, to znamená, že se žáci jako skupina vymezují vůči svým učitelům a činí tak právě i prostřednictvím humoru.

A konečně: ačkoli humor může být nevhodný a zraňující, častěji přináší emoce pozitivní a úlevné. $Z$ tohoto důvodu bývá někdy označován jako „okysličovač“ školního života, nebot' skrze dočasné převrácení zaběhaného pořádku přináší oživující vytržení ze soustředěné práce.

\section{Literatura}

Bariaud, F. (1989). Age differences in children humor. In P. E. McGhee (Ed.), Humor and children's development: A guide to practical applications (pp. 13-45). New York, London: The Haworth Press.

Bergson, H. (1994). Smích. Praha: Naše vojsko.

Bingham, S. Ch., \& Hernandez, A. A. (2009). „Laughing matters“: The comedian as sociological observer, teacher, and conduit of the sociological perspective. Teaching Sociology, 37(3), 335-352.

Carlson, K. A. (2011). The input of humor on memory: Is the humor effect about humor? Humor, 24(1), 21-41.

Dunleavy, K. N. (2006). The effect of instructor humor on percieved instructor credibility, student state motivation, and student motives to communicate in the classroom. Kentucky Journal of Communication, 25(1), 39-56.

Freud, S. (1995). Totem a tabu. Vtip a jeho vztah k nevědomí: teoretická část. Praha: Práh.

Garner, R. L. (2006). Humor in pedagogy. How ha-ha can lead to aha. College Teaching, 54(1), 177-180.

Gorham, J., \& Christophel, D. M. (1990). The relationship of teachers' use of humor in the classroom to immediacy and student learning. Communication Education, 39(1), 46-62.

Huuki, T., Manninen, S., \& Sunnari, V. (2010). Humour as a resource and strategy for boys to gain status in the field of informal school. Gender and Education, 22(4), 369-383.

Klein, D. N., \& Kuiper, N. A. (2006). Humor styles, peer relationships and bullying in middle childhood. Humor, 19(4), 38-404.

Koller, M. J. (1988). Humor and society: Explorations in the sociology of humor. Houston: Cap and Gown Press.

LaFave, L. (1972) Humor judgments as a function of reference groups and identification classes. In J. H. Goldstein \& P. E. McGhee (Eds.), The psychology of humor (s. 196-210). New YorkLondon: Academic Press.

Lahelma, E. (2002). School is for meeting friends: Secondary school as lived and remembered. British Journal of Sociology of Education, 23(3), 367-383.

Mareš, J., \& Křivohlavý, J. (1995). Komunikace ve škole. Brno: Masarykova univerzita.

Martin, R. A. (2007). The psychology of humor. An integrattive approach. London, New York: Elsevier.

Martineau, W. H. (1972). A model of the social functions of humor. In J. H. Goldstein \& P. E. McGhee (Eds.), The psychology of humor (pp.10-15). New York, London: Academic Press. 
Matrazzo, K. L., Durik, A. M., \& Delaney, M. L. (2010). The effect of humorous instructional materials on interest in a math task. Motivation and Emotion, 34(3), 29-305.

Meeus, W., \& Mahieu, P. (2009). You can see the funny side, can't you? Pupil humour with the teacher as target. Educational Studies, 35(5), 553-560.

Mulkay, M. (1988). On humor: Its nature and place in modern society. New York: Basil Blackwell. Riessman, C. K. (2008). Narrative methods for the human sciences. Thousand Oaks: Sage.

Švaříček, R., \& Šed’ová, K. et al. (2007). Kvalitativní výzkum v pedagogických vědách. Praha: Portál.

Wanzer, M. B., Frymier, A. B., \& Irwin, J. (2010). An explanation of the relationship between instructor humor and student learning: Instructional humor processing theory. Communication Education, 59(1), 1-18.

Watzlawick, P., \& Beavin-Bavelasová, J. (2000). Pragmatika lidské komunikace: interakční vzorce, patologie a paradoxy. Hradec Králové: Konfrontace.

Wolfenstein, M. (1978). Children's humor. A psychological analysis. Bloomington, London: Indiana University Press.

Woods, P. (1979). The divided school. London: Routledge.

Woods, P. (1983). Coping at school through humor. British Journal of Sociology of Education, 4(2), $111-124$

Woods, P. (1986). Inside schools. Ethnography in educational research. London: Routledge.

Ziv, A. (1976). Facilitating effects of humor on creativity. Journal of Educational Psychology, 68(3), 318-322.

Ziv, A. (2010). The social function of humor in interpersonal relationships. Society, 47(1) 11-18.

\title{
Autorka
}

Mgr. Klára Šed’ová, Ph.D., Masarykova univerzita, Filozofická fakulta, Ústav pedagogických věd, A. Nováka 1, 60200 Brno, e-mail: ksedova@phil.muni.cz

\section{Pupils laugh at teachers: the forms and functions of teacher-focused school humour}

\begin{abstract}
The article is related to the issue of pupil humor aimed at teachers in the setting of lower secondary schools and is based on an analysis of pupils' written narratives. The data are categorized according to various situational modes in which the teachers find themselves as objects of humor - unintended comic mode, mode of pupil snare and mode of teacher joke. The analysis shows a number of functions of the school humor, especially in terms of acceptable expression of hostile feelings among pupils and teachers.
\end{abstract}

Keywords: teacher, pupils, school, humour, functions of humour 